\title{
PELAKSANAAN AKAD MUDHARABAH \\ DI BMT TUMANG SURAKARTA: ANALISA FATWA DSN- MUI NO.07/DSN-MUI/IV/2000 TENTANG PEMBIAYAAN MUDHARABAH
}

\author{
Sumadi \\ Institut Teknologi Bisnis AAS Indonesia \\ Suprihati \\ Institut Teknologi Bisnis AAS Indonesia \\ Eko Verdianto \\ Institut Teknologi Bisnis AAS Indonesia
}

\begin{abstract}
ABSTRAK
Penelitian ini bertujuan untuk mengetahui pelaksanaan Akad Mudharabah di BMT Tumang cabang Surakarta sesuai dengan fatwa DSNMUI No. 07/DSN- MUI/IV/2000 atau belum. Penelitian ini dilakukan di BMT Tumang cabang Surakarta. Teknik analisis data pada penelitian ini menggunakan metode deskriptif analisis dengan menggunakan pendekatan kualitatif. Hasil penelitian menunjukkan bahwa pelaksanaan pembiayaan Mudharabah di BMT Tumang belum sepenuhnya sesuai dengan Fatwa DSN N0: 07/DSN-MUI/IV/2000. Hal yang belum sesuai dengan Fatwa DSN N0: 07/DSN-MUI/IV/2000 yaitu 1) apabila mudharib mengalami kerugian yang tidak disengaja seharusnya kerugian di tanggung oleh BMT Tumang, tetapi BMT Tumang belum bisa menanggung kerugian, jika terjadi kerugian mudharib diminta mengembalikan pokok saja namun apabila mudharib tetap tidak sanggup maka BMT Tumang terpaksa mencairkan jaminan. 2) Jaminan sebenarnya hanya bisa dicairkan untuk mudharib yang terbukti melakukan kesalahan yang disengaja, namun di BMT Tumang jaminan juga akan dicairkan ketika mudharib mengalami kerugian yang sudah diberi keringanan untuk membayar pokoknya saja tetap tidak bisa menjalankan setorannya maka dengan terpaksa BMT Tumang akan mencairkan jaminan tersebut.
\end{abstract}

\section{Kata Kunci : Pembiayaan, Mudharabah, FATWA DSN-MUI}

\section{ABSTRACT}

This study aims to determine the implementation of the Mudharabah Agreement at BMT Tumang Surakarta in accordance with the DSN-MUI fatwa no. 07/DSN-MUI/IV/2000 or not. This research was conducted at BMT Tumang Surakarta. The data analysis technique in this study used a descriptive analysis method using a qualitative approach. The results 
showed that the implementation of Mudharabah financing at BMT Tumang was not fully in accordance with the Fatwa of DSN N0:07/DSNMUI/IV/2000. Things that are not in accordance with DSN Fatwa N0:07/DSN-MUI/IV/2000, namely if the mudharib suffers an unintentional loss, the loss should be borne by BMT Tumang, but BMT Tumang cannot bear the loss, if there is a loss, the mudharib is asked to return the principal only. But if mudharib still can't afford it then BMT Tumang is forced to disburse the guarantee. 2) The actual guarantee can only be disbursed for the mudharib who is proven to have committed an intentional mistake, but at BMT Tumang the guarantee will also be disbursed when the mudharib suffers a loss who has been given relief to pay the principal but still cannot carry out the deposit, then BMT Tumang will be forced to withdraw the guarantee.

\section{Keywords: Financing, Mudharabah, DSN-MUI FATWA}

\section{A. PENDAHULUAN}

Lembaga keuangan syari'ah terbagi menjadi lembaga keuangan syariah bank dan non-bank, keduanya mempunyai peranan yang penting dalam menjaga pertumbuhan ekonomi masyarakat di Indonesia. Salah satu lembaga keuangan non-bank yaitu BMT (Baitul Maal Wattamwil), secara umum BMT (Baitul Maal Wattamwil) terdiri dari dua istilah, yaitu baitul maal dan baitul tamwil. Baitul maal lebih mengarah pada usahausaha pengumpulan dan penyaluran dana yang non-profit, seperti; zakat, infaq dan sedekah, sedangkan baitul tamwil sebagai usaha pengumpulan dan penyaluran dana komersil. Usaha-usaha tersebut menjadi bagian yang tidak terpisahkan dari BMT sebagai lembaga pendukung kegiatan ekonomi masyarakat kecil dengan berlandaskan syari'ah. Peran umum BMT yang dilakukan adalah melakukan pembinaan dan pendanaan yang berdasarkan sistem syari'ah. Peran ini menegaskan arti penting prinsip-prinsip syari'ah dalam kehidupan ekonomi masyarakat, dan sebagai lembaga keuangan syari'ah yang bersentuhan langsung dengan kehidupan masyarakat kecil, maka BMT mempunyai tugas penting dalam mengemban misi keislaman dalam 
segala aspek kehidupan masyarakat. ${ }^{1}$

Mudharabah adalah penanaman dana dari pemilik dana (shahibul maal) kepada pengelola dana (mudharib) untuk melakukan kegiatan usaha tertentu, dengan pembagian menggunakan metode bagi untung dan rugi (profit and loss sharing) atau metode bagi pendapatan (revenue sharing) antara kedua belah pihak berdasarkan nisbah yang telah disepakati sebelumnya. Keuntungan tanggung jawab atas pengelola usaha. Keuntungan dibagikan sesuai dengan rasio laba yang telah disepakati bersama, mana kala rugi shahibul maal akan menanggung kerugian sebesar pembiayaaan yang disediakan, sedangkan mudharib menanggung kerugian tenaga, waktu, dan kehilangan nisbah keuntungan bagi hasil yang akan diperolehnya. Penghitungan perolehan margin harus berupa nisbah (persentase) laba, tidak diperbolehkan menyebut nilai nominal mata uang secara pasti. Selain harus berupa persentase, margin juga harus sesuai dengan kesepakatan bersama antara kedua belah pihak yaitu shahibul maal dengan mudharib. Karena tanpa adanya kesepakatan akan menimbulkan adanya rasa ketidakadilan pada masing-masing pihak. ${ }^{2}$

Berdasarkan Rapat Pleno Dewan Syari'ah Nasional pada hari Selasa, tanggal 29 Dzulhijjah 1420 H./4 April 2000, memutuskan Fatwa Dewan Syari'ah Nasional No: 07/DSN MUI/IV/2000 tentang pembiayaan mudharabah (Qiradh). Dalam keputusannya tersebut menetapkan fatwa tentang pembiayaan mudharabah (Qiradh), dalam ketentuan pembiayaan dipoin keenam bahwa "LKS sebagai penyedia dana menanggung semua kerugian akibat dari mudharabah kecuali jika mudharib (nasabah) melakukan kesalahan yang disengaja, lalai, atau menyalahi perjanjian". Menurut fatwa DSN Indonesia No. 07/DSN-MUI/IV/2000 tentang Pembiayaan Mudharabah (Qiradh) didalam rukun dan syarat

\footnotetext{
${ }^{1}$ Sudarsono Heri, Bank \& Lembaga Keuangan Syari'ah Deskripsi Dan Ilustrasi (Yogyakarta: Ekonesia, 2004).

2 Ascaraya, Akad Dan Produk Bank Syariah. (Jakarta: Raja Grafindo Persada, 2008).
} 
disebutkan bahwa "Keuntungan mudharabah adalah jumlah yang didapat sebagai kelebihan dari modal". Adapun Syarat keuntungan yang harus dipenuhi, adalah sebagai berikut:

Pertama, Harus diperuntukkan bagi keduabelah pihak dan tidak boleh disyaratkan hanya untuk satu pihak.

Kedua, Pembagian keuntungan proporsional bagi setiap pihak serta harus diketahui dan dinyatakan pada waktu kontrak disepakati dan harus dalam bentuk prosentasi (nisbah) dari keuntungan, sesuai kesepakatan. Perubahan nisbah harus berdasarkan kesepakatan.

Ketiga, Penyedia dana menanggung semua kerugian akibat dari mudharabah, dan pengelola tidak boleh menanggung kerugian apapun kecuali diakibatkan dari kesalahan disengaja, kelalaian, atau pelanggaran kesepakatan.

Adapun Metode penelitian ini menggunakan pendekatan kualitatif dengan pendekatan deskriptif. Metode penelitian kualitatif adalah metode penelitian yang berlandaskan pada filsafat post positivisme, digunakan untuk meneliti pada kondisi obyek yang alamiah, (sebagai lawannya eksperimen) dimana peneliti adalah sebagai instrumen kunci, pengambilan sampel sumber data dilakukan secara purposive dan snowball, teknik pengumpulan dengan tri-anggulasi (gabungan), analisis data bersifat induktif atau kualitatif, dan hasil penelitian kualitatif lebih menekankan makna dari pada generalisasi. ${ }^{3}$ Sumber Data Primer yaitu data yang diperoleh langsung dari subyek penelitian dengan menggunakan alat pengukuran atau alat pengambilan data langsung pada subyek sebagai sumber informasi yang dicari. Dalam penelitian ini keterangan didapatkan dari pihak manajemen BMT Tumang Boyolali dan nasabah yang melakukan transaksi mudharabah dengan BMT Tumang cabang Kartasura. Data sekunder adalah data yang diperoleh 2018).

3 Sugiyono, Metode Penelitian Kuantitatif, Kualitatif, Dan RED, Alfabeta. (Bandung, 
lewat pihak lain, tidak langsung diperoleh oleh peneliti dari subjek penelitiannya. ${ }^{4}$

Teknik analisis data pada penelitian ini menggunakan metode deskriptif analisis dengan menggunakan pendekatan kualitatif. analisis deskriptif, yaitu prosedur pemecahan masalah yang diselidiki dengan menggambarkan /melukiskan keadaan subjek/objek penelitian (seorang, lembaga, masyarakat dan lain-lain) pada saat sekarang berdasarkan fakta - fakta yang tampak atau sebagaimana adanya.Penelitian ini penulis mencari data - data dengan menggunakan teknik pengumpulan data seperti wawancara, observasi dan dokumentasi yang relevan dengan judul penelitian. Selanjutnya penulis juga mencari gagasan hukum yang mempunyai relevansi dengan pembiayaan mudharabah, seperti dokumen fatwa dari DSN-MUI Nomor 07 tahun 2000 tentang pembiayaan mudharabah, dan data-data lainnya yang dapat berisi tentang pelaksanaan pembiayaan mudharabah, sehingga ditemukan kedudukan hukum Islam dari pembiayaan mudharabah. ${ }^{5}$

\section{B. Pengertian Mudharabah}

Mudharabah adalah bahasa yang digunakan oleh penduduk Irak, sedangkan penduduk Hijaz menyebut mudharabah dengan istilah mudharabah atau qiradh, sehingga dalam perkembangan lebih lanjut mudharabah dan qiradh juga mengacu pada makna yang sama. Mudharabah secara etimologi berasal dari bahasa arab yaitu darb, yang memiliki arti memukul, berdetak, mengalir, berenang, bergabung, menghindar berubah, mencampur, berjalan, dan lain sebagainya. Secara terminologi mudharabah adalah bentuk kontrak (perjanjian) antara pemilik modal (shahibul maal) dan pengguna dana (mudharib) untuk digunakan aktivitas yang produktif di mana keuntungan dibagi kedua belah pihak antara

${ }^{4}$ Anwar Syaifuddin, Metode Penelitian (Yogyakarta: Pustaka Pelajar, 1991).

${ }^{5}$ Nawawi Ismail, Fikih Muamalah Klasik Dan Kontemporer (Surabaya: Ghalia Indonesia, 2012). 
pemilik modal dan pengelola dana. Apabila terjadi kerugian ditanggung oleh pemilik modal, jika kerugian itu terjadi dalam keadaan normal, pemodal (shahibul maal) tidak boleh intervensi kepada pengelola dana (mudharib) dalam menjalankan usahanya. ${ }^{6}$

Mudharabah menurut berbagai mazhab yaitu Madzhab Hanafi mendefinisikan mudharabah adalah akad atas suatu syarikat dalam keuntungan dengan modal harta dari satu pihak dan dengan pekerjan (usaha) dari pihak yang lain. Madzhab Maliki mendefinisikan mudharabah adalah penyerahan uang dimuka oleh pemilik modal dalam jumlah uang yang ditentukan kepada seorang yang akan menjalankan usaha dengan uang itu dengan imbalan sebagian dari keuntungannya. Madzhab Syafi`i mendefinisikan mudharabah adalah suatu akad yang memuat penyerahan modal kepada orang lain untuk mengusahakannya dan keuntungannya dibagi antara mereka berdua. Madzhab Hambali mendefinisikan mudharabah adalah penyerahan suatu barang atau sejenisnya dalam jumlah yang jelas dan tertentu kepada orang yang mengusahakannya dengan mendapatkan bagian tertentu dari keuntungannya. ${ }^{7}$

Pengertian Mudharabah menurut beberapa sumber buku, mudharabah adalah penanaman dana dari pemilik dana (shahibul maal) kepada pengelola dana (mudharib) untuk melakukan kegiatan usaha tertentu, dengan pembagian menggunakan metode bagi untung dan rugi (profit and loss sharing) atau metode bagi pendapatan (revenue sharing) antara kedua belah pihak berdasarkan nisbah yang telah disepakati sebelumnya., mudharabah adalah akad antar pihak pemilik modal (shahibul maal) dengan pengelola (mudharib) untuk memperoleh pendapatan atau keuntungan. Pendapatan atau keuntungan tersebut

\footnotetext{
${ }^{6}$ Albisri dan Munawwir Adib, Al-Bisri Kamus Arab - Indonesia, Indonesia - Arab (Surabaya: Pustaka Progressif, 1999).

7 Fauzan Mohammad, "Penerapan Fatwa DSN-MUI NO.07/DSN- MUI/IV/2000 Tentang Mudharabah DI PT. BNI Syariah Cabang," Jurnal Studi Agama (2019).
} 
dibagi berdasarkan nisbah yang telah disepakati di awal akad. Ismail, mudharabah adalah akad perjanjian antara dua pihak atau lebih untuk melakukan kerja sama usaha, satu sebagai penyedia modal sebesar 100\% yang disebut sebagai Shahibul Maal dan pihak lainnya sebagai pengelola usaha yang disebut sebagai Mudharib. ${ }^{8}$

Menurut Zuhaily mudharabah adalah akad kerja sama usaha antara dua pihak. Pihak pertama bertindak sebagai pemilik dana (shahibul maal) yang menyediakan seluruh modal dan pihak kedua sebagai pengelola dana (mudharib). Keuntungan yang didapatkan dari akad mudharabah dibagi menurut kesepakatan yang dituangkan dalam kontrak dan biasanya dalam bentuk presentase (nisbah). ${ }^{9}$ Berdasarkan fatwa DSN-MUI No.07/DSN-MUI/IV/2000, definisi mudharabah adalah pembiayaan yang disalurkan oleh lembaga keuangan syariah kepada pihak lain untuk membuka suatu usaha yang produktif. Dalam pembiayaan ini posisi lembaga keuangan sebagai pemilik dana dan membiayai 100\% atas usaha pengelola, sedangkan posisi pengelola sebagai mudharib.

\section{Dasar Hukum Mudharabah}

Landasan dasar penerapan sistem mudharabah pada prinsipnya terbagi kepada dua landasan hukum, yaitu landasan berdasarkan hukum Islam (Alqur'an, hadist, ijma' dan qiyas) dan landasan berdasarkan UndangUndang perbankan yang berlaku di Indonesia (Sahrani dan Abdullah, 2011).

a. Al-Qur'an

1) QS Al Jumu'ah: 10

Artinya :"Apabila salat telah dilaksanakan, maka bertebaranlah kamu di bumi; carilah karunia Allah dan ingatlah Allah banyak-banyak agar kamu beruntung." (QS. Al Jumu'ah: 10)

\footnotetext{
8 Ismail, Perbankan Syari'ah (Jakarta: Kencana Prenada Media Grup, 2005).

${ }^{9}$ Wahbah Az-Zuhaili, Fiqih Islam Wa Adillatuhu Jilid 5, Jakarta : Gema Insani, 2011, hlm. 476
} 
2) QS. Al Muzammil: 20

Artinya: "...dan orang-orang yang berjalan di muka bumi mencari sebagian karunia Allah..." (QS. Al Muzammil: 20)

b. Al-Hadist

Rasulullah SAW bersabda :

Artinya : Dari Saleh bin Suhaib r.a, bahwa Rasulullah SAW bersabda : Tiga hal didalamnya terdapat keberkatan yaitu jual beli secara tangguh, muqaradhah (mudharabah), dan mencampur gandum dengan tepung untuk keperluan rumah bukan untuk dijual ( HR Ibnu Majah).

c. Ijma dan Qiyas

Imam Zailai telah menyatakan bahwa para sahabat telah berkonsensus terhadap legitimasi pengolahan harta yatim secara mudharabah. Qiyas merupakan dalil lain yang membolehkan mudharabah dengan mengqiyaskannya (analogi) kepada transaksi musaqat, yaitu bagi hasil yang umum dilakukan dalam bidang perkebunan. Dalam hal ini, pemilik kebun bekerja sama dengan orang lain dengan pekerjaan menyiram, memelihara dan merawat isi perkebunan. Dalam perjanjian ini, sang perawat (penyiram) mendapatkan bagi hasil tertentu sesuai dengan kesepakatan di depan dari out put perkebunan (pertanian).

Dalam mudharabah, pemilik dana (shahibul maal) dianalogikan dengan pemilik kebun, sedangkan pemeliharaan kebun dianalogikan dengan pengusaha (entrepreneur. Dari landasan hukum tersebut diatas bisa dipahami bahwa mudharabah disyariatkan oleh firman Allah, hadist, ijma' dan qiyas dan yang diberlakukan pada masa Rasulullah saw dan beliau tidak melarangnya, karena manusia dapat saling bermanfaat untuk orang lain.

D. Rukun, Syarat dan Prinsip 


\section{Mudharabah 10}

Rukun dalam mudharabah berdasarkan Jumhur Ulama ada tiga, yaitu: dua orang yang melakukan akad (al-aqidani), modal (ma'qud alaih), dan shighat (ijab dan qabul). Sedangkan menurut ulama Syafi'iyah lebih memerinci lagi menjadi enam rukun, yaitu:
a. Pemilik modal (shohibul maal).
b. Pelaksanaan usaha (mudharib atau pengusaha).
c. Akad dari kedua belah pihak (ijab dan qabul).
d. Objek mudharabah (pokok atau modal).
e. Usaha (pekerjaan pengelola modal).
f. Nisbah keuntungan.

Syarat-syarat mudharabah adalah sebagai berikut:

a. Akad

Syarat yang terkait dengan orang yang melakukan akad (Aqidain), yaitu:

1) Cakap bertindak hukum dan cakap diangkat sebagai orang yang berakad (aqid).

2) Pemilik dana tidak boleh mengikat dan melakukan intervensi kepada pengelola dana.

b. Modal

Syarat terkait dengan modal, antara lain yaitu:

1) Modal harus diketahui secara pasti termasuk jenis mata uangnya.

2) Modal harus dalam bentuk tunai, seandainya berbentuk aset diperbolehkan asalkan berbentuk barang niaga dan memiliki nilai atau historinya pada saat mengadakan kontrak.

3) Besarnya ditentukan secara jelas di awal akad.

${ }^{10}$ Afandi M. Yazid, Fiqh Muamalah Dan Implementasinya Dalam Lembaga Keuangan Syariah. (Yogyakarta: Logung Pustaka, 2009). 
4) Modal bukan merupakan pinjaman (hutang).

5) Modal diserahkan langsung kepada pengelola dana dan secara tunai.

6) Modal digunakan sesuai dengan syarat-syarat akad yang disepakati.

7) Pengembalian modal dapat dilakukan bersamaan dengan waktu penyerahan bagi hasil atau pada saat berakhirnya masa akad mudharabah.

c. Keuntungan

Syarat yang terkait dengan keuntungan, antara lain yaitu:

1) Keuntungan dibagi sesuai dengan kesepakatan.

2) Pemilik dana siap mengambil risiko rugi dari modal yang dikelola.

3) Penentuan angka keuntungan dihitung dengan persentase hasil usaha yang dikelola oleh pengelola dana berdasarkan kesepakatan kedua belah pihak.

4) Pengelola dana hanya bertanggung jawab atas sejumlah modal yang telah di investasikan dalam usaha.

5) Pengelola dana berhak memotong biaya yang berkaitan dengan usaha yang diambil dari modal mudharabah.

d. Kegiatan Usaha

Kegiatan usaha oleh pengelola (mudharib), sebagai pertimbangan (muqabil) modal yang disediakan oleh penyedia dana, harus memperhatikan hal-hal berikut:

1) Kegiatan usaha adalah hak eksklusif mudharib, tanpa campur tangan penyedia dana, tetapi ia mempunyai hak untuk melakukan pengawasan.

2) Penyedia dana tidak boleh mempersempit tindakan pengelola sedemikian rupa yang dapat menghalangi tercapainya tujuan 
mudharabah, yaitu keuntungan.

3) Pengelola tidak boleh menyalai hukum syariah islam dalam tindakannya yang berhubungan dengan mudharabah, dan harus mematuhi kebiasaan yang berlaku dalam aktivitas itu, prinsip-prinsip yang harus dijalankan dalam pembiayaan mudharabah adalah sebagai berikut:

a. Prinsip berbagi keuntungan di antara pihak-pihak yang melakukan akad mudharabah. Laba bersih yang telah diperoleh harus dibagi antara pemilik dana dan pengelola dana secara adil sesuai dengan porsi yang sebelumnya telah disepakati oleh kedua belah pihak. Pembagian laba ini harus dilakukan setelah adanya pengurangan biaya-biaya dan juga modal dari pemilik dana telah dikembalikan secara utuh.

b. Prinsip bagi kerugian di antara masing-masing pihak yang berakad.

Dalam mudharabah, asas keseimbangan dan keadilan terletak pada pembagian kerugian apabila usaha yang dijalankan pengelola dana mengalami kerugian. Kerugian tersebut dapat ditanggung oleh pemilik dana, akan tetapi apabila terbukti ada kelalaian yang dilakukan oleh pengelola dana, maka pengelola dana yang akan menanggung kerugian tersebut.

c. Prinsip kejelasan. Sebelum melakukan kontrak mudharabah ini, antara pemilik dana dan pengelola dana harus jelas dalam menyatakan modal yang disertakan, syarat-syarat, porsi bagi hasil yang akan diterima oleh masing-masing pihak dan juga jangka waktu berlakunya akad tersebut.

d. Prinsip kepercayaan dan amanah. Unsur terpenting dalam melaksanakan akad mudharabah ini adalah saling percaya. Pemilik dana mempercayakan dananya untuk dikelola oleh pengelola dana (mudharib). Pemilik dana bisa saja membatalkan 
kontrak perjanjian akad mudharabah tersebut apabila sudah tidak ada rasa saling percaya.

e. Prinsip kehati-hatian. Prinsip kehati-hatian menjadi kunci keberhasilan dari berlangsungnya akad mudharabah. Apabila prinsip kehati-hatian ini tidak dimiliki oleh masing-masing pihak, maka yang terjadi akan menimbulkan kerugian finansial, waktu, dan juga tenaga.

\section{E. Jenis - jenis Mudharabah}

Pembiayaan dengan prinsip mudharabah terdiri dari dua jenis, yaitu: ${ }^{11}$

\section{a. Mudharabah Muthlaqah}

Muthlaqah merupakan akad mudharabah yang digunakan untuk kegiatan usaha yang cakupannya tidak dibatasi oleh spesifikasi jenis usaha, waktu dan daerah bisnis sesuai dengan permintaan pemilik dana (shahibul maal). Pembiayaan mudharabah muthlaqah juga disebut dengan investasi pemilik dana kepada bank syari'ah. Bank syari'ah tidak mempunyai kewajiban untuk mengganti rugi atas pengelolaan dana yang bukan disebabkan kelalaian atau kesalahan bank sebagai Mudharib. Sebaliknya, apabila kesalahan atau kelalaian dalam mengelola dana investor (Shahibul Maal) dilakukan secara sengaja, maka bank syari'ah wajib mengganti semua dana Investasi Mudharabah Mutlaqah. Penerapan mudharabah muthlaqah dapat berupa tabungan dan deposito sehingga terdapat dua jenis himpunan dana yaitu mudharabah dan deposito mudharabah. Berdasarkan prinsip ini tidak ada pembatasan dalam menggunakan dana yang dihimpun.

b. Mudharabah Muqayyadah

${ }^{11}$ Muhammad, Manajemen Dana Bank Syariah (Jakarta: Rajawali Pres, 2014). 
Muqayyadah merupakan akad mudharabah yang mana dalam melakukan kegiatan usahanya, pemilik dana (shahibul maal) memberikan syarat-syarat tertentu atau dibatasi dengan adanya spesifikasi tertentu kepada pengelola dana. Adanya pembatasan ini sering kali mencerminkan kecenderungan umum si shahibul maal dalam jenis dunia usaha. Mudharabah muqayyadah atau disebut juga dengan istilah restricted mudharabah atau specified mudharabah adalah kebalikan dari mudharabah muthlaqah. Akad mudharabah muqayyadah ada dua macam, yaitu:

1) Mudharabah Muqayyadah On Balance Sheet, yaitu akad kerja sama usaha yang mana mudharib ikut menanggung resiko atas kerugian dana yang diinvestasikan oleh Shahibul Maal. Dalam akad ini, Shahibul Maal juga memberi batasan secara umum misalnya, batasan tentang jenis usaha, jangka waktu pembiayaan, dan sektor usahanya. Karakteristik jenis simpanan ini; Pertama, pemilik dana harus wajib menetapkan syarat atau membuat akad yang wajib di penuhi oleh Mudharib. Kedua, bank wajib memberitahu pemilik dana mengenai nisbah dan tata cara bagi hasil serta pembagian secara risiko yang dicantumkan dalam akad. Ketiga, sebagai tanda bukti simpanan, bank menerbitkan bukti simpanan khusus yang memisahkan dana dari rekening lainnya. Keempat, untuk Deposito Mudharabah, bank wajib memberikan sertifikat atau tanda penyimpanan (bilyet) deposito kepada deposan.

2) Mudharabah Muqayyadah Of Balance Sheet, yaitu jenis mudharabah yang merupakan penyaluran dana mudharabah langsung kepada pelaksana usahanya, dimana bank bertindak sebagai perantara yang mempertemukan antara pemilik dana dengan pelaksana usaha. Pemilik dana dapat menetapkan syarat- syarat tertentu yang harus dipenuhi oleh bank dalam mencari kegiatan usaha yang akan dibiayai 
dan pelaksanaan usahanya. Karakteristik jenis penyimpanan ini diantaranya Pertama, sebagai tanda bukti simpanan, bank menerbitkan bukti simpanan khusus yang memisahkan dana dari rekening lainnya. Simpanan khusus dicatat pada pos tersendiri dalam rekening administratif. Kedua, dana simpanan khusus harus disalurkan langsung kapada pihak yang diamanatkan oleh pemilik dana. Ketiga, bank menerima komisi atas jasanya mempertemukan kedua belah pihak. Sedangkan antara pemilik dana dan pelaksana usaha berlaku nisbah bagi hasil.

\section{F. Fatwa DSN-MUI No. 07/DSN-MUI/IV/2000 tentang}

\section{Pembiayaan Mudharabah}

a. Ketentuan Pembiayaan:

1) Pembiayaan Mudharabah adalah pembiayaan yang disalurkan oleh LKS kepada pihak lain untuk suatu usaha yang produktif.

2) Dalam pembiayaan ini LKS sebagai shahibul maal (pemilik dana) membiayai 100 \% kebutuhan suatu proyek (usaha), sedangkan pengusaha (nasabah) bertindak sebagai mudharib atau pengelola usaha.

3) Jangka waktu usaha, tatacara pengembalian dana, dan pembagian keuntungan ditentukan berdasarkan kesepakatan kedua belah pihak (LKS dengan pengusaha).

4) Mudharib boleh melakukan berbagai macam usaha yang telah disepakati bersama dan sesuai dengan syari'ah; dan LKS tidak ikut serta dalam managemen perusahaan atau proyek tetapi mempunyai hak untuk melakukan pembinaan dan pengawasan.

5) Jumlah dana pembiayaan harus dinyatakan dengan jelas dalam bentuk tunai dan bukan piutang.

6) LKS sebagai penyedia dana menanggung semua kerugian akibat dari mudharabah kecuali jika mudharib (nasabah) melakukan kesalahan yang disengaja, lalai, atau menyalahi perjanjian. 
7) Pada prinsipnya, dalam pembiayaan mudharabah tidak ada jaminan, namun agar mudharib tidak melakukan penyimpangan, LKS dapat meminta jaminan dari mudharib atau pihak ketiga. Jaminan ini hanya dapat dicairkan apabila mudharib terbukti melakukan pelanggaran terhadap hal-hal yang telah disepakati bersama dalam akad.

8) Kriteria pengusaha, prosedur pembiayaan, dan mekanisme pembagian keuntungan diatur oleh LKS dengan memperhatikan fatwa DSN.

9) Biaya operasional dibebankan kepada mudharib.

10) Dalam hal penyandang dana (LKS) tidak melakukan kewajiban atau melakukan pelanggaran terhadap kesepakatan, mudharib berhak mendapat ganti rugi atau biaya yang telah dikeluarkan.

b. Rukun dan Syarat Pembiayaan:

1) Penyedia dana (sahibul maal) dan pengelola (mudharib) harus cakap hukum.

2) Pernyataan ijab dan qabul harus dinyatakan oleh para pihak untuk menunjukkan kehendak mereka dalam mengadakan kontrak (akad), dengan memperhatikan hal-hal berikut:

a) Penawaran dan penerimaan harus secara eksplisit menunjukkan tujuan kontrak (akad).

b) Penerimaan dari penawaran dilakukan pada saat kontrak.

c) Akad dituangkan secara tertulis, melalui korespondensi, atau dengan menggunakan cara- cara komunikasi modern.

3) Modal ialah sejumlah uang dan/atau aset yang diberikan oleh penyedia dana kepada mudharib untuk tujuan usaha dengan syarat sebagai berikut: 
a) Modal harus diketahui jumlah dan jenisnya.

b) Modal dapat berbentuk uang atau barang yang dinilai. Jika modal diberikan dalam bentuk aset, maka aset tersebut harus dinilai pada waktu akad.

c) Modal tidak dapat berbentuk piutang dan harus dibayarkan kepada mudharib, baik secara bertahap maupun tidak, sesuai dengan kesepakatan dalam akad.

4) Keuntungan mudharabah adalah jumlah yang didapat sebagai kelebihan dari modal. Syarat keuntungan berikut ini harus dipenuhi:

a) Harus diperuntukkan bagi kedua pihak dan tidak boleh disyaratkan hanya untuk satu pihak.

b) Bagian keuntungan proporsional bagi setiap pihak harus diketahui dan dinyatakan pada waktu kontrak disepakati dan harus dalam bentuk prosentasi (nisbah) dari keun-tungan sesuai kesepakatan. Perubahan nisbah harus berdasarkan kesepakatan.

c) Penyedia dana menanggung semua kerugian akibat dari mudharabah, dan pengelola tidak boleh menanggung kerugian apapun kecuali diakibatkan dari kesalahan disengaja, kelalaian, atau pelanggaran kesepakatan.

5) Kegiatan usaha oleh pengelola (mudharib), sebagai perimbangan (muqabil) modal yang disediakan oleh penyedia dana, harus memperhatikan hal-hal berikut:

a) Kegiatan usaha adalah hak eksklusif mudharib, tanpa campur tangan penyedia dana, tetapi ia mempunyai hak untuk melakukan pengawasan.

b) Penyedia dana tidak boleh mempersempit tindakan pengelola sedemikian rupa yang dapat menghalangi tercapainya tujuan mudharabah, yaitu keuntungan. 
c) Pengelola tidak boleh menyalahi hukum Syari'ah Islam dalam tindakannya yang berhubungan dengan mudhara-bah, dan harus mematuhi kebiasaan yang berlaku dalam aktifitas itu.

c. Beberapa Ketentuan Hukum Pembiayaan;

1) Mudharabah boleh dibatasi pada periode tertentu.

2) Kontrak tidak boleh dikaitkan (mu'allaq) dengan sebuah kejadian di masa depan yang belum tentu terjadi.

3) Pada dasarnya, dalam mudharabah tidak ada ganti rugi, karena pada dasarnya akad ini bersifat amanah (yad al-amanah), kecuali akibat dari kesalahan disengaja, kelalaian, atau pelanggaran kesepakatan.

4) Jika salah satu pihak tidak menunaikan kewajibannya atau jika terjadi perselisihan di antara kedua belah pihak, maka penyelesaiannya dilakukan melalui Badan Arbitrasi Syari'ah setelah tidak tercapai kesepakatan melalui musyawarah.

G. Analisis kesesuaian pelaksanaan Pembiayaan Mudharabah di BMT Tumang Cabang Kartasura dengan fatwa DSN-MUI No.07/DSNMUI/IV/2000

\section{Ketentuan Pembiayaan}

Hasil analisis menunjukkan bahwa pembiayaan mudharabah di BMT Tumang merupakan pembiyaan yang diberikan kepada anggota untuk keperluan usaha yang produktif, bukan untuk keperluan usaha yang konsumtif. Hal ini sesuai dengan Fatwa DSN N0:07/DSNMUI/IV/2000 bagian pertama poin pertama yang menyatakan bahwa pembiayaan mudharabah adalah pembiayaan yang disalurkan oleh LKS kepada pihak lain untuk suatu usaha yang produktif. Pembiayaan produktif adalah pembiayaan yang ditujukan untuk memenuhi kebutuhan produksi dalam arti luas yaitu untuk peningkatan usaha baik 
usaha produksi, perdagangan maupun investasi. ${ }^{12}$

Pembiayaan mudharabah di BMT Tumang tidak ada potongan dana sama sekali, ini berarti BMT Tumang selaku shahibul maal membiayai suatu proyek atau usaha sesuai dengan nominal yang telah tertera didalam perjanjian tanpa potongan apapun, adapun biaya administrasi dibayarkan terpisah oleh anggota selaku mudharib. Hal ini sesuai dengan Fatwa DSN N0:07/DSN-MUI/IV/2000 bagian pertama poin kedua yang menyatakan bahwa dalam pembiayaan ini LKS sebagai shahibul maal (pemilik dana) membiayai $100 \%$ kebutuhan suatu proyek (usaha), sedangkan pengusaha (nasabah) bertindak sebagai mudharib atau pengelola usaha. Kedua belah pihak pada pembiayaan mudharabah baik dari BMT Tumang selaku shahibul maal (pemilik dana) maupun anggota selaku mudharib (pengelola usaha) telah memahami dan mengerti perjanjian yang telah mereka sepakati, didalam perjanjian tersebut sudah mencakup penentuan jangka waktu pembiayaan, tata cara pengembalian dana, pembagian prosentase keuntungan. Hal ini sesuai dengan Fatwa DSN N0:07/DSN-MUI/IV/2000 bagian pertama poin ketiga yang menyatakan bahwa jangka waktu usaha, tatacara pengembalian dana, dan pembagian keuntungan ditentukan berdasarkan kesepakatan kedua belah pihak (LKS dengan pengusaha).

BMT Tumang selaku shahibul maal (pemilik dana) memperbolehkan anggota selaku mudharib (pengelola usaha) untuk melaksanakan berbagai jenis usaha dengan syarat usaha tersebut tidak melanggar syari'ah dan BMT Tumang harus mengetahui jenis usaha yang dijalankan tersebut. BMT Tumang tidak ikut dalam manajemen usaha yang dijalankan oleh mudharib (pengelola usaha), hanya saja BMT Tumang melakukan pengawasan serta pembinaan terhadap usaha yang dijalankan. Hal ini sesuai dengan Fatwa DSN N0:07/DSN-MUI/IV/2000 bagian pertama poin empat yang menyatakan bahwa mudharib boleh melakukan

${ }^{12}$ Antonio, Muhammad Syafi'I. Bank Syariah: dari teori ke praktik. Gema Insani, 2001. 
berbagai macam usaha yang telah disepakati bersama dan sesuai dengan syari'ah dan LKS tidak ikut serta dalam managemen perusahaan atau proyek tetapi mempunyai hak untuk melakukan pembinaan dan pengawasan.

Dana yang diberikan BMT Tumang selaku shahibul maal (pemilik dana) kepada anggota selaku mudharib (pengelola usaha) adalah berupa tunai dan nominalnya sesuai dengan perjanjian yang telah disepakati. Hal ini sesuai dengan Fatwa DSN N0:07/DSN-MUI/IV/2000 bagian pertama poin lima yang menyatakan bahwa jumlah dana pembiayaan harus dinyatakan dengan jelas dalam bentuk tunai dan bukan piutang.

Usaha yang dijalankan oleh anggota selaku mudharib (pengelola usaha) diharapkan selalu memperoleh keuntungan sehingga bermanfaat untuk umat dan setoran pembiayaan mudharabah bisa berjalan lancar, tetapi didalam dunia usaha adakalanya anggota selaku mudharib (pengelola usaha) mengalami kerugian sehingga tidak bisa menjalankan setoran yang telah disepakati bersama. Seharusnya jika terjadi kerugian pihak BMT Tumang selaku shahibul maal atau penyedia dana menanggung semua kerugian dengan ketentuan kerugian tidak disebabkan oleh kelalaian atau kesengajaan mudharib, namun sayangnya BMT Tumang belum bisa melaksanakannya, untuk mudharib yang mempunyai iktikad baik penyelesaian jika terjadi kerugian dilakukan dengan cara kekeluargaan yaitu dengan memberi keringanan menghilangkan bagi hasil jadi seperti qardh, mudharib hanya diminta mengembalikan pokoknya saja, akan tetapi jika memang sudah benar benar diusahakan tetap tidak bisa membayar setoran walaupun sudah diberi keringanan hanya pokoknya saja, terpaksa dari pihak BMT Tumang akan melakukan eksekusi jaminan.

Hal ini tidak sesuai dengan Fatwa DSN N0:07/DSN-MUI/IV/2000 bagian pertama poin enam yang menyatakan bahwa LKS sebagai penyedia dana menanggung semua kerugian akibat dari 
mudharabah kecuali jika mudharib (nasabah) melakukan kesalahan yang disengaja, lalai, atau menyalahi perjanjian. Pembiayaan mudharabah di BMT Tumang tidak mensyaratkan jaminan, tetapi BMT Tumang meminta jaminan agar mudharib tidak melakukan penyimpangan atau kesalahan yang disengaja, hal ini sesuai dengan Fatwa DSN N0:07/DSN-MUI/IV/2000 bagian pertama poin tujuh awal yang menyatakan bahwa pada prinsipnya, dalam pembiayaan mudharabah tidak ada jaminan, namun agar mudharib tidak melakukan penyimpangan, LKS dapat meminta jaminan dari mudharib atau pihak ketiga.

Jaminan sebenarnya hanya bisa dicairkan untuk mudharib yang terbukti melakukan penyelewengan atau kesalahan yang disengaja, namun di BMT Tumang tidak hanya dicairkan ketika mudharib melakukan kesalahan saja akan tetapi terpaksa dicairkan juga ketika mudharib mengalami kerugian yang sudah benar benar diusahakan diberi keringanan untuk membayar pokoknya saja tetap tidak bisa juga menjalankan setorannya maka dengan terpaksa BMT Tumang akan mencairkan jaminan tersebut, hal ini tidak sesuai dengan Fatwa DSN N0:07/DSN- MUI/IV/2000 bagian pertama poin tujuh akhir yang menyatakan bahwa jaminan ini hanya dapat dicairkan apabila mudharib terbukti melakukan pelanggaran terhadap hal-hal yang telah disepakati bersama dalam akad.

BMT Tumang dalam menjalankan Pembiayaan mudharabah yang meliputi kriteria mudharib, prosedur pembiayaan mudharabah, serta mekanisme pembagian keuntungan dalam pembiayaan mudharabah sudah dilaksanakan dengan memperhatikan fatwa DSN. Hal ini sesuai dengan Fatwa DSN N0:07/DSN-MUI/IV/2000 bagian pertama poin delapan yang menyatakan bahwa Kriteria pengusaha, prosedur pembiayaan, dan mekanisme pembagian keuntungan diatur oleh LKS dengan memperhatikan fatwa DSN. Pembiayaan 
mudharabah di BMT Tumang membebankan biaya administrasi kepada anggota selaku mudharib (pengelola usaha). Hal ini sesuai dengan Fatwa DSN N0:07/DSN-MUI/IV/2000 bagian pertama poin sembilan yang menyatakan bahwa Biaya operasional dibebankan kepada mudharib.

BMT Tumang selaku shahibul maal (pemilik dana) mempunyai kewajiban dan aturan yang harus dilaksanakan sesuai kesepakatan, tetapi apabila terbukti BMT Tumang tidak melakukan kewajiban atau melakukan pelangganggaran atas kesepakatan, maka BMT Tumang bersedia bertanggung jawab membayar ganti rugi atau biaya yang telah di keluarkan oleh anggota selaku mudharib (pengelola usaha). Hal ini sesuai dengan Fatwa DSN N0:07/DSN-MUI/IV/2000 bagian pertama poin sepuluh yang menyatakan bahwa dalam hal penyandang dana (LKS) tidak melakukan kewajiban atau melakukan pelanggaran terhadap kesepakatan, mudharib berhak mendapat ganti rugi atau biaya yang telah dikeluarkan.

\section{Rukun dan Syarat Pembiayaan}

BMT Tumang selaku shahibul maal (pemilik dana) dalam pembiayaan mudharabah sudah memahami hukum dengan baik dan selalu memastikan bahwa anggota selaku mudharib (pengelola usaha) cakap hukum mengacu pada UU kriteria seseorang dikatakan cakap hukum dalam Pasal 330 Kitab UUH Perdata menyatakan: “Seseorang dianggap sudah dewasa jika sudah berusia 21 tahun atau sudah (pernah) menikah". Apabila pembiayaan mudharabah mencapai nilai lebih dari 20 juta pada waktu perjanjian kedua belah pihak dihadapkan dengan notaris, jadi notaris juga akan bisa menilai kecakapan hukum dari kedua belah pihak yang melakukan perjanjian. Hal ini sesuai dengan Fatwa DSN N0:07/DSN-MUI/IV/2000 bagian kedua poin satu yang menyatakan bahwa penyedia dana (sahibul maal) dan pengelola (mudharib) harus cakap hukum. 
BMT Tumang selaku shahibul maal (pemilik dana) dan anggota selaku mudharib (pengelola usaha) pada saat membuat kesepakatan dan menandatangani akad kedua belah pihak sudah berkomunisasi secara langsung mengungkapkan dengan jelas tujuan perjanjian dan maksud kontrak tersebut, akan tetapi selain dengan lisan akad pembiayaan mudharabah ini juga tertulis dalam form akad perjanjian yang didalamnya memuat pasal pasal. Hal ini sesuai dengan Fatwa DSN N0:07/DSN- MUI/IV/2000 bagian kedua poin dua yang menyatakan bahwa Pernyataan ijab dan qabul harus dinyatakan oleh para pihak untuk menunjukkan kehendak mereka dalam mengadakan kontrak (akad), dengan memperhatikan hal-hal berikut: Penawaran dan penerimaan harus secara eksplisit menunjukkan tujuan kontrak (akad). Penerimaan dari penawaran dilakukan pada saat kontrak. Akad dituangkan secara tertulis, melalui korespondensi, atau dengan menggunakan cara-cara komunikasi modern.

Modal yang diberikan oleh BMT Tumang selaku shahibul maal (pemilik dana) kepada anggota selaku mudharib (pengelola usaha) diberikan secara tunai sesuai nominal yang telah disepakati pada perjanjian. Hal ini sesuai dengan Fatwa DSN N0:07/DSN-MUI/IV/2000 bagian kedua poin tiga yang menyatakan bahwa Modal ialah sejumlah uang dan/atau aset yang diberikan oleh penyedia dana kepada mudharib untuk tujuan usaha dengan syarat sebagai berikut: Modal harus diketahui jumlah dan jenisnya. Modal dapat berbentuk uang atau barang yang dinilai, jika modal diberikan dalam bentuk aset, maka aset tersebut harus dinilai pada waktu akad. Modal tidak dapat berbentuk piutang dan harus dibayarkan kepada mudharib, baik secara bertahap maupun tidak, sesuai dengan kesepakatan dalam akad. Keuntungan mudharabah diperuntukkan untuk BMT Tumang selaku shahibul maal (pemilik dana) dan anggota selaku mudharib (pengelola usaha) yang prosentase pembagian keuntungannya sudah disepakati 
antara kedua belah pihak didalam perjanjian. Hal ini sesuai dengan Fatwa DSN N0:07/DSN-MUI/IV/2000 bagian kedua poin empat a dan b yang menyatakan bahwa Keuntungan mudharabah adalah jumlah yang didapat sebagai kelebihan dari modal. Syarat keuntungan berikut ini harus dipenuhi: Harus diperuntukkan bagi kedua pihak dan tidak boleh disyaratkan hanya untuk satu pihak. Bagian keuntungan proporsional bagi setiap pihak harus diketahui dan dinyatakan pada waktu kontrak disepakati dan harus dalam bentuk prosentasi (nisbah) dari keuntungan sesuai kesepakatan. Perubahan nisbah harus berdasarkan kesepakatan.

Usaha yang dijalankan oleh anggota selaku mudharib (pengelola usaha) apabila mengalami kerugian sehingga mudharib (pengelola usaha) tidak bisa menjalankan setoran yang telah disepakati bersama, maka seharusnya kerugian yang terjadi ditanggung oleh pihak BMT Tumang selaku shahibul maal atau penyedia dana dengan ketentuan kerugian tidak disebabkan oleh kelalaian atau kesengajaan mudharib, namun sayangnya BMT Tumang belum bisa melaksanakannya, untuk mudharib yang mempunyai iktikad baik penyelesaian jika terjadi kerugian dilakukan dengan cara kekeluargaan yaitu dengan memberi keringanan menghilangkan bagi hasil jadi seperti qardh, mudharib hanya diminta mengembalikan pokoknya saja, tidak ada tindakan keras, akan tetapi jika memang sudah benar-benar diusahakan tetap tidak bisa membayar setoran walaupun sudah diberi keringanan hanya pokoknya saja, terpaksa dari pihak BMT Tumang akan melakukan eksekusi jaminan. Hal ini tidak sesuai dengan Fatwa DSN N0:07/DSNMUI/IV/2000 bagian kedua poin empat c yang menyatakan bahwa Penyedia dana menanggung semua kerugian akibat dari mudharabah, dan pengelola tidak boleh menanggung kerugian apapun kecuali diakibatkan dari kesalahan disengaja, kelalaian, atau pelanggaran kesepakatan. 
BMT Tumang selaku shahibul maal (pemilik dana) memberi hak sepenuhnya kepada anggota selaku mudharib (pengelola usaha) mengenai jenis usaha dan manajemen pengelolaan usaha, tetapi BMT Tumang tetap melakukan pengawasan dan memberi saran yang membangun untuk apabila diperlukan. Meskipun demikian mudharib tetap harus menjalankan usaha dengan pembiayaan mudharabah ini dengan tidak menyalahi hukum syari'ah islam. Hal ini sesuai dengan Fatwa DSN N0:07/DSN- MUI/IV/2000 bagian kedua poin lima yang menyatakan bahwa Kegiatan usaha oleh pengelola (mudharib), sebagai perimbangan (muqabil) modal yang disediakan oleh penyedia dana, harus memperhatikan hal-hal berikut: Kegiatan usaha adalah hak eksklusif mudharib, tanpa campur tangan penyedia dana, tetapi ia mempunyai hak untuk melakukan pengawasan. Penyedia dana tidak boleh mempersempit tindakan pengelola sedemikian rupa yang dapat menghalangi tercapainya tujuan mudharabah, yaitu keuntungan. Pengelola tidak boleh menyalahi hukum Syari'ah Islam dalam tindakannya yang berhubungan dengan mudhara-bah, dan harus mematuhi kebiasaan yang berlaku dalam aktifitas itu.

3. Ketentuan Hukum Pembiayaan

BMT Tumang menjalankan pembiayaan produktif dengan akad mudharabah dengan periode tertentu sesuai kesepakatan antara BMT Tumang selaku shahibul maal (pemilik dana) dan anggota selaku mudharib (pengelola usaha). Hal ini sesuai dengan Fatwa DSN N0:07/DSN-MUI/IV/2000 bagian ketiga poin satu yang menyatakan bahwa mudharabah boleh dibatasi pada periode tertentu. Kontrak perjanjian pembiayaan mudharabah di BMT Tumang tidak mengaitkan dengan kejadian yang akan datang karena belum pasti. Hal ini sesuai dengan Fatwa DSN N0:07/DSN-MUI/IV/2000 bagian ketiga poin dua yang menyatakan bahwa Kontrak tidak boleh dikaitkan (mu'allaq) dengan sebuah kejadian di masa depan yang belum tentu 
terjadi.

Anggota selaku mudharib (pengelola usaha) dalam menjalankan usaha apabila mengalami kerugian yang tidak disengaja dan bukan kelalaian mudharib, seharusnya kerugian yang terjadi ditanggung oleh pihak BMT Tumang selaku shahibul maal atau penyedia dana, namun BMT Tumang belum bisa melaksanakannya, untuk mudharib yang mempunyai iktikad baik penyelesaian jika terjadi kerugian dilakukan dengan cara kekeluargaan yaitu dengan memberi keringanan menghilangkan bagi hasil jadi seperti qardh, mudharib hanya diminta mengembalikan pokoknya saja, akan tetapi jika memang sudah benar benar diusahakan tetap tidak bisa membayar setoran walaupun sudah diberi keringanan hanya pokoknya saja, terpaksa dari pihak BMT Tumang akan melakukan eksekusi jaminan.Hal ini tidak sesuai dengan Fatwa DSN N0:07/DSN-MUI/IV/2000 bagian ketiga poin tiga yang menyatakan bahwa Pada dasarnya, dalam mudharabah tidak ada ganti rugi, karena pada dasarnya akad ini bersifat amanah (yad al-amanah), kecuali akibat dari kesalahan disengaja, kelalaian, atau pelanggaran kesepakatan.

BMT Tumang selaku shahibul maal (pemilik dana) dan anggota selaku mudharib (pengelola usaha) dalam melakukan pembiayaan mudharabah berharap bisa bekerjasama menjalankan kewajiban masing masing dan menjalin hubungan yang baik. Seiring berjalannya waktu apabila salah satu pihak tidak melakukan kewajibannya, melakukan kesalahan yang disengaja, atau ada perselisihan antara kedua belah pihak, jalan yang akan diambil pertama adalah secara kekeluargaan dengan cara bermusyawarah antara kedua belah pihak, namun jika terpaksanya tidak diperoleh mufakat dalam bermusyawarah maka penyelesaian dilakukan melalui Badan Arbitrasi Syari'ah. Hal ini sesuai dengan Fatwa DSN N0:07/DSN-MUI/IV/2000 bagian ketiga poin empat yang menyatakan bahwa Jika salah satu 
pihak tidak menunaikan kewajibannya atau jika terjadi perselisihan di antara kedua belah pihak, maka penyelesaiannya dilakukan melalui Badan Arbitrasi Syari'ah setelah tidak tercapai kesepakatan melalui musyawarah.

\section{H.PENUTUP}

Hasil penelitian menunjukkan bahwa pelaksanaan pembiayaan Mudharabah di BMT Tumang belum sepenuhnya sesuai dengan Fatwa DSN N0:07/DSN-MUI/IV/2000. Hal yang belum sesuai dengan Fatwa DSN N0:07/DSN-MUI/IV/2000 yaitu: Pada saat terjadi kerugian apabila mengalami kerugian sehingga mudharib (pengelola usaha) tidak bisa menjalankan setoran yang telah disepakati bersama, maka seharusnya kerugian yang terjadi ditanggung oleh pihak BMT Tumang selaku shahibul maal atau penyedia dana dengan ketentuan kerugian tidak disebabkan oleh kelalaian atau kesengajaan mudharib, namun sayangnya BMT Tumang belum bisa melaksanakannya, untuk mudharib yang mempunyai iktikad baik penyelesaian jika terjadi kerugian dilakukan dengan cara kekeluargaan yaitu dengan memberi keringanan menghilangkan bagi hasil jadi seperti qardh, mudharib hanya diminta mengembalikan pokoknya saja, akan tetapi jika memang sudah benar benar diusahakan tetap tidak bisa membayar setoran walaupun sudah diberi keringanan hanya pokoknya saja, terpaksa dari pihak BMT Tumang akan melakukan eksekusi jaminan.

Dengan demikian Jaminan sebenarnya hanya bisa dicairkan untuk mudharib yang terbukti melakukan penyelewengan atau kesalahan yang disengaja, namun di BMT Tumang tidak hanya dicairkan ketika mudharib melakukan kesalahan saja akan tetapi terpaksa dicairkan juga ketika mudharib mengalami kerugian yang sudah benar benar diusahakan diberi keringanan untuk membayar pokoknya saja tetap tidak bisa juga menjalankan setorannya maka dengan terpaksa BMT 
Tumang akan mencairkan jaminan tersebut.

\section{DAFTAR PUSTAKA}

Adib, Albisri dan Munawwir. Al-Bisri Kamus Arab - Indonesia, Indonesia Arab. Surabaya: Pustaka Progressif, 1999.

Antonio, Muhammad Syafi'I. Bank Syariah: dari teori ke praktik. Gema Insani, 2001.

Ascaraya. Akad Dan Produk Bank Syariah. Jakarta: Raja Grafindo Persada, 2008.

Heri, Sudarsono. Bank E Lembaga Keuangan Syari'ah Deskripsi Dan Ilustrasi. Yogyakarta: Ekonesia, 2004.

Ismail. Perbankan Syari'ah. Jakarta: Kencana Prenada Media Grup, 2005.

Ismail, Nawawi. Fikih Muamalah Klasik Dan Kontemporer. Surabaya: Ghalia Indonesia, 2012.

M. Yazid, Afandi. Fiqh Muamalah Dan Implementasinya Dalam Lembaga Keuangan Syariah. Yogyakarta: Logung Pustaka, 2009.

Mohammad, Fauzan. "Penerapan Fatwa DSN-MUI NO.07/DSNMUI/IV/2000 Tentang Mudharabah DI PT. BNI Syariah Cabang." Jurnal Studi Agama (2019).

Muhammad. Manajemen Dana Bank Syariah. Jakarta: Rajawali Pres, 2014. Sugiyono. Metode Penelitian Kuantitatif, Kualitatif, Dan RED. Alfabeta. Bandung, 2018.

Syaifuddin, Anwar. Metode Penelitian. Yogyakarta: Pustaka Pelajar, 1991.

Wahbah Az-Zuhaili, Fiqih Islam Wa Adillatuhu Jilid 5, Jakarta : Gema Insani, 2011, hlm. 476 
